Military Technical College

Kobry El-Kobbah,

Cairo, Egypt

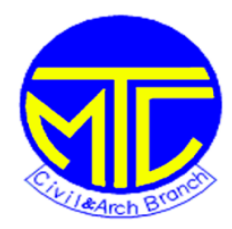

12 $^{\text {th }}$ International Conference on Civil and Architecture Engineering

\author{
ICCAE-12-2018
}

\title{
Geophysical/Geotechnical investigation for earthquake risk mitigation of the strategic and development projects, South Egypt
}

\author{
Abdelnasser Mohamed \\ NRIAG, Aswan Earthquake Research Center
}

\begin{abstract}
Many strategic and development projects were achieved in southern part of Egypt (e.g. Aswan High Dam, New Aswan city, New Tushka city, Aswan cement factory, Wadi Kurkur development project). The Aswan High Dam is one of the most important projects of the last century in Egypt. It provides Egypt with water and electricity, and secures the country from the risk of the destructive inundation of the River Nile. After the occurrence of 14 November, 1981 earthquake $\left(\mathrm{M}_{\mathrm{b}}\right.$ 5.6) $60 \mathrm{~km}$ southwest Aswan High Dam, Aswan seismic network was installed in Aswan area. The main target of the network is the monitoring of the seismic activity in and around the northern part of Aswan Lake for High Dam stability. Before the construction of Aswan network, there was a lack of the recorded seismic data in southern Egypt. So, after the continues recording from this network since 1982 up to date, a good contribution with a complete catalogue for earthquake hazard assessment in the new development projects became available for southern part of Egypt. For successful assessment and mitigation of earthquake hazards, it is necessary to be able to predict the level of ground shaking which has to be expected from future large earthquakes. Therefore, many geophysical and geotechnical studies were performed in the development project sites during the planning stage using different techniques for site characterization to mitigate the earthquake hazard in these projects. The outputs of these studies are very important for solving the problems, which associated with the construction of various civil engineering purposes, for land use planning and for earthquakes resistant structure design.
\end{abstract}

\section{Introduction}

Two thirds of deaths arising from natural hazards in recent decades have been caused by geophysical disasters. Most resulted from earthquakes and their consequences but other primary and secondary geophysical hazards such as those from volcanoes, landslides and tsunamis, have also been significant contributors (Rees et al., 2012). According to Daniell et al. (2011), over 2 million people died in earthquakes during the 20th century; approximately $75 \%$ of those deaths were caused by building collapse. The economic costs of earthquakes over the same interval amounted to about $\$ 2$ trillion. So, earthquake risk mitigation using advanced methodologies is of major importance for the reduction of seismic hazard in urban areas.

Generally, the damage due to an earthquake is large over soft sediments than on firm bedrock outcrops. Also it is a well-known fact that in low shear-wave velocity areas in most cases site amplification/shaking is stronger. A key parameter to evaluate the dynamic properties of near-surface soil and for characterizing the given site is the shallow shear-wave velocity structure 
to a depth of $30 \mathrm{~m}$.

Based on travel time from the surface to a depth of $30 \mathrm{~m}$, the average shear-wave velocity in the top $30 \mathrm{~m}$ is known as $\mathrm{V}_{\mathrm{S} 30}$. A site classification scheme based on $\mathrm{V}_{\mathrm{S} 30}$ values was proposed by the National Earthquake Hazards Reduction Program (NEHRP) to separate sites into different classes (BSSC, 2003). The classifications are then used to determine the seismic coefficients for earthquake-resistant design. The expectation is that sites in the same class will respond similarly to a given earthquake. 
[Type here]

The geophysical and geotechnical methods are the primary sources of information that are used to minimize and mitigate the earthquake risks posed by ground conditions, so the geophysical/geotechnical investigations is the required step to perform tests to collect geophysical data and geotechnical soil properties to provide information for detailed site characterization at any new project in planning stage. The obtained information from the investigations will help to ensure the project is designed and constructed to be safe, reliable, and cost effective.

The main target of the current study is the applications of different Geophysical techniques for site investigation at the development projects in southern part of Egypt.

\section{Earthquake Activity in South Egypt}

Before the installation of Aswan seismic network, a few numbers of large earthquakes occurred in Red Sea and one in Gulf El-Kebir had been reported in Upper Egypt, because the closest station to record earthquakes in Upper Egypt was Helwan station (690 km from Aswan), it wasn't possible to determine the low magnitude activity from Upper Egypt. The first seismographs installed in Upper Egypt region that were capable of recording small local earthquakes were Soviet short-period (SMK) instruments installed at Aswan and Abu-Simbel in 1975.

During the period from June 19, 1984 to January 4, 1985, the National Research Institute of Astronomy and Geophysics (NRIAG) installed a temporary seismic network by three seismic stations (MEQ-800) including the Abu Dabbab station around Abu Dabbab area. In 1990 a portable short period seismic station was installed in Marsa Alam along the Red Sea coast to monitor the seismic activity in Abu-Dabbab area and Red Sea.

According to the spatial distribution of earthquakes that located in southern part of Egypt, several areas having different seismicity level such as Shedwan Island, Red Sea, Abu Dabbab, Eastern Desert, Kalabsha, and Western Desert.

In these areas several significant earthquakes occurred (Fig. 1), among these events are the following:

\section{November 12, Abu-Dabbab Earthquake}

The most important event included inside Abu Dabbab area source is the $\mathrm{M}_{\mathrm{S}}$ 5.3, November 12, 1955 earthquake. This event was felt in Aswan and Qena cities, and as far as Cairo, but no damage was reported. The depth of this event is not well constrained but it is clearly within the crust.

\section{March 31, Shedwan Island Earthquake}

The magnitude of this earthquake was $6.3(\mathrm{mb})$ with a maximum intensity of IX in a small part of the Shedwan Island, not with standing the scarcity of the population in Shedwan, which consisted of a few army units. On the island, land slides, earth slumps and rock falls were common. Fissures and cracks in soil were found with a main direction nearly parallel to Red SeaGulf of Suez direction.

\section{December 9, Gilf El-Kebir Earthquake}

This is the largest instrumentally located earthquake in the south western region of Egypt. This event had a magnitude of 5.3 and focal depth of about 7 to $10 \mathrm{~km}$. The southern part of Egypt is an unpopulated desert and the intensity distribution of this earthquake is not estimated. 
[Type here]

Proceedings of the $12^{\text {th }}$ ICCAE-12 Conference, 3-5 April, 2018

The nearest station to the epicenter of this earthquake was Helwan, $850 \mathrm{~km}$ away. Neither foreshocks nor aftershocks were recorded for this earthquake.

\section{November 14, Kalabsha Earthquake}

This earthquake had a magnitude of 5.6 (mb) Kebeasy et al. (1982) and it is of significance because of its possible association with High Dam (Nasser's) Lake. Although its epicenter is located in Kalabsha area about $60 \mathrm{Km}$ southwest of Aswan, it was strongly felt in Aswan, and in areas to the north up to Assuit and to the South up to Khartoum. The intensity near the epicenter is between VII and VIII. The focal depth of this earthquake is estimated to be 25 $\mathrm{Km}$.

\section{July 2, Abu-Dabbab Earthquake}

This earthquake had a magnitude of 5.1 and was strongly felt in Aswan, Qena and Quseir. Five portable field stations were operated in the Abu-Dabbab area from June 19, 1984 till the end of August of 1984. Large number of foreshocks and an extensive sequence of aftershocks were recorded. The focal depths of the whole sequence were less than $12 \mathrm{~km}$.

The seismicity of Shedwan Island, Red Sea, Abu Dabbab, Eastern Desert, Abu Simbel and Western Desert are less significant to the Aswan region area relative to Kalabsha area, so the later are significant and discussed in the following:

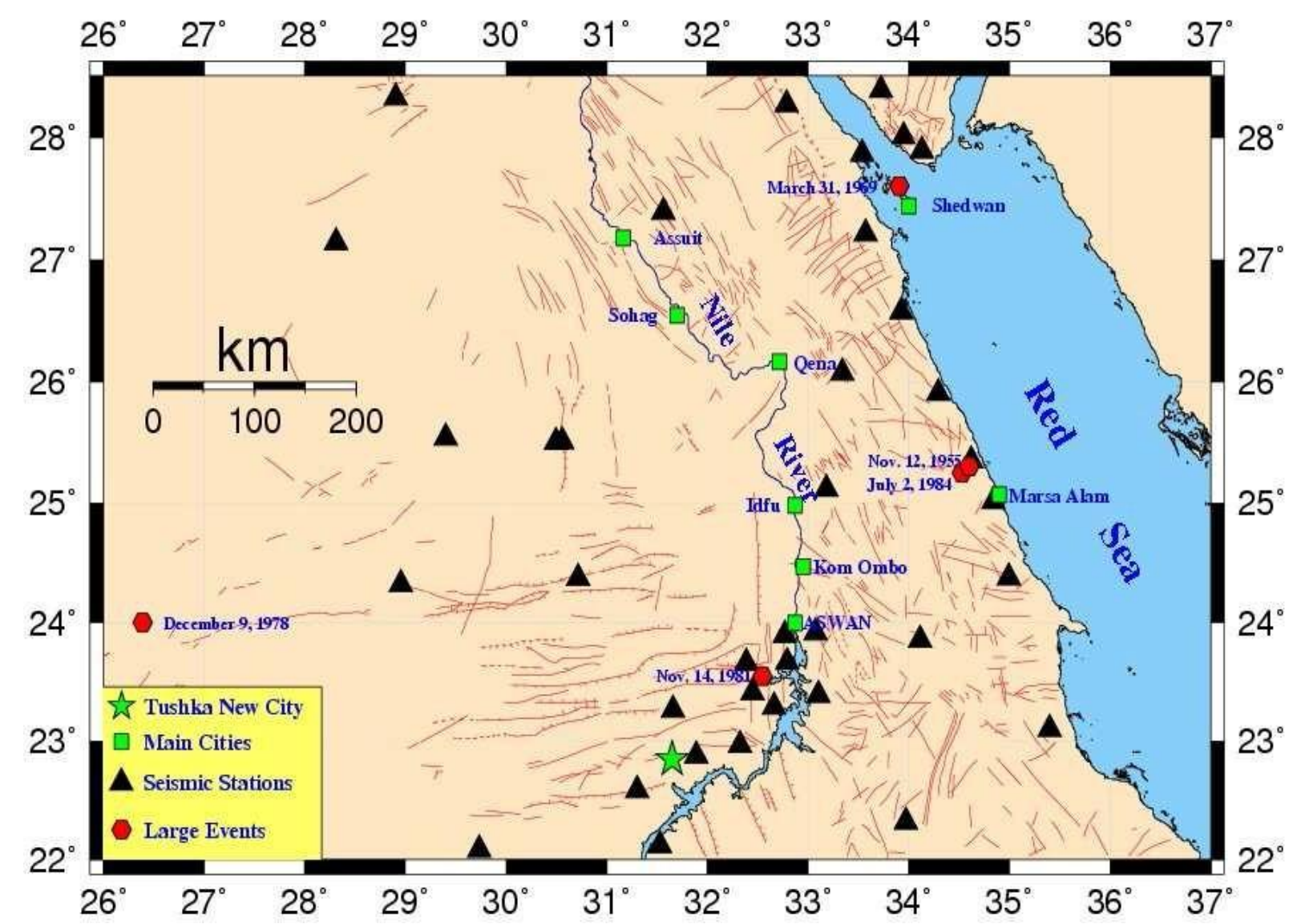

Figure 1. Significant earthquakes in southern part of Egypt. 
[Type here]

Proceedings of the $12^{\text {th }}$ ICCAE-12 Conference, 3-5 April, 2018

\section{Structural setting and seismicity of Aswan area}

Woodward-Clyde Consultants (1985) evaluated the fault system in the Kalabsha area and reported that the Western Desert Fault System consists of two sets of faults, (E-W) faults that exhibit dextral-slip displacement, and (N-S) that exhibit sinistral-slip displacement (Fig. 2). The E-W trending faults as the Kalabsha and Seiyal faults, which lay to the west of High Dam Lake. The Kalabsha Fault is about $185 \mathrm{~km}$. The N-S trending faults can be subdivided into two main sets: The first set lies to the NW of High Dam Lake and consists of three faults: the Gebel ElBarqa fault, the Khor El-Ramla fault and the Kurkur fault. The Gebel El-Barqa is a left-lateral strike-slip fault, with a total length of $110 \mathrm{~km}$. The Khor El-Ramla fault is about $36 \mathrm{~km}$ in length, and it has no direct indication of its sense of movement. The Kurkur fault is characterized by its low seismic activity if compared with the neighbor faults and is a left-lateral strike-slip fault. The second set of faults is lying to the SW of High Dam Lake, and consists mainly of two faults: the Ghazala and the Abu Dirwa faults. Abu Dirwa fault is a $20 \mathrm{~km}$ long left-lateral strike-slip fault and it has a very low degree of seismic activity. In addition, for the Gazelle fault, the analysis of its geomorphic expression shows no active features, and that there is no ground cracks observed along the fault trace. Likely this fault is inactive (Issawi, 1968). To the east of High Dam Lake, the third fault system trending NNE-SSW is laying. The Dabud fault, which represents the main fault of this group, is about $36 \mathrm{~km}$ length. Geological evidences indicate reverse-slip, opposed to the tectonic setting of the area.

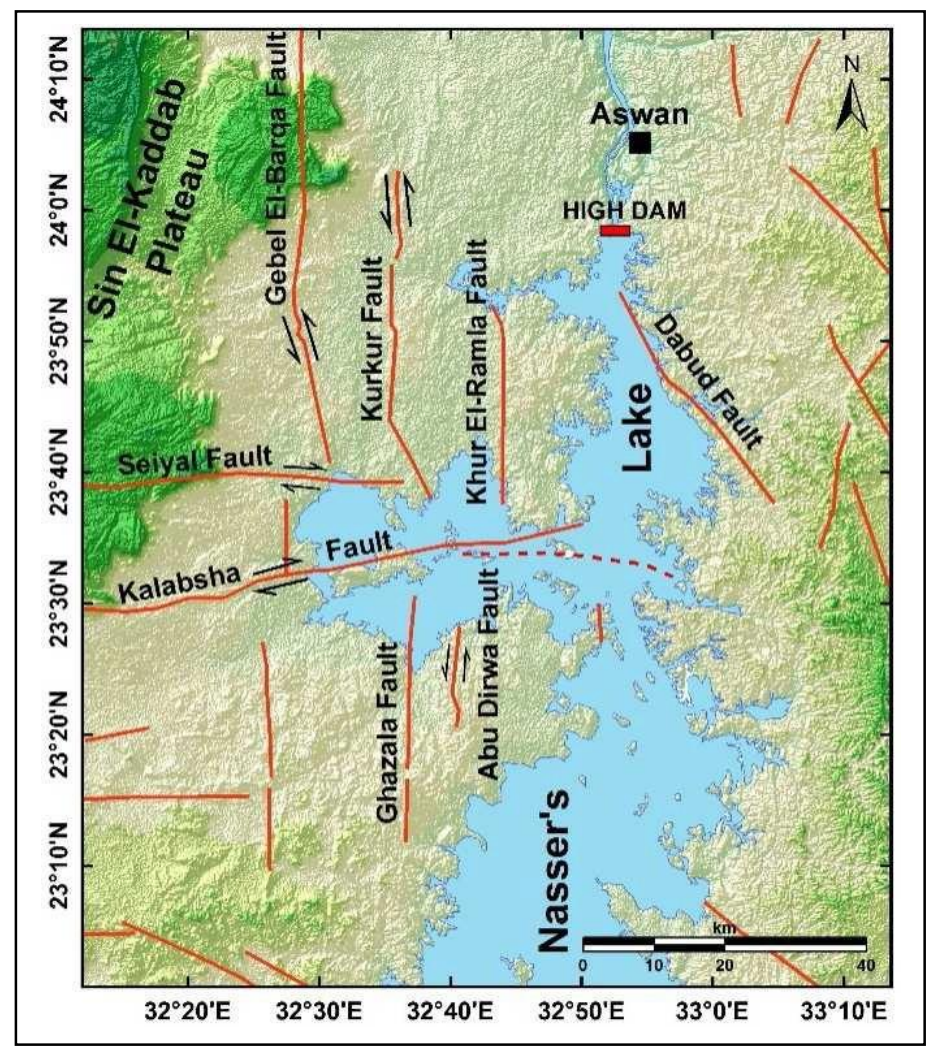

Figure 2. Western Desert Fault System around Nasser's Lake (after WCC, 1985). 
[Type here]

Proceedings of the $12^{\text {th }}$ ICCAE-12 Conference, 3-5 April, 2018

The main earthquake that took place inside the Aswan region was the $\left(\mathrm{M}_{\mathrm{b}}\right.$ 5.6) November 14, 1981 event (Kebeasy et al., 1982). This earthquake occurred in the Nubian Desert of Aswan. It is of great significance because of its possible association with High Dam Lake. Although its epicenter is located in Kalabsha area about $60 \mathrm{Km}$ southwest of Aswan. Its effects were strongly in Aswan, and in areas up to Assiut city (440 km to the North from Kalabsha fault), as well as to Khartoum city ( $870 \mathrm{~km}$ to the South). Several cracks on the western bank of the High Dam Lake, and several rock-falls and minor cracks on the eastern bank are reported. The composite fault plane solution of this event indicates a nearly pure strike-slip faulting with a normal-fault component (Fat-Helbary and Tealeb, 2002; Fat-Helbary, 1989). This event caused alarm due to its proximity to the Aswan High Dam, so in 1982, Aswan seismic network erected by the National Research Institute of Astronomy and Geophysics (NRIAG) and High and Aswan Dam Authority.

The seismic stations of this network have a good distribution around the two sets of faults (NS and EW directions) at the northern part of High Dam Lake. Aswan seismic network has thirteen seismic stations, eleven stations on the western side and two stations on the eastern side of the High Dam Lake. After construction the Egyptian National Seismic Network (ENSN) which covers all the Egyptian territory, the Aswan seismic network became an important branch from the ENSN covering the southern region of Egypt. There was a lack of the recorded seismic data in southern Egypt before the construction of Aswan network, therefore after the continues recording through this network since 1982 up to date, a good contribution with a complete catalogue for seismic hazard studies became available not only for Aswan region but for all the Egyptian territory. A catalogue for the period from June 1982 to 2017 is used for constructing the seismicity map of the Kalabsha area as shown in Figure (3). The space distribution of the earthquakes constructing the seismicity map of Aswan area shows that the seismicity is concentrated around the faults in the area. All the seismic activity in this area has a shallow focal depth less than $30 \mathrm{~km}$.

\section{Applied Geophysical methods}

There are very large numbers of geophysical techniques available for characterization of subsurface soils. Each of the method has its own advantages and also limitations over other methods. There is always an ambiguity over the selection of a particular method for site characterization. Selection of a particular method depends upon the many factors starting from the purpose and the scope of the study, availability of resources (equipment and expertise personal), type of analysis to be carried, type of soil, etc. Geophysical/Geotechnical investigations require for earthquake risk mitigation (seismic microzonation) are different from the conventional site investigations. Moreover, microzonation studies require dynamic site characterization from the perspective, of earthquake loading. So, it is very important to plan site investigations properly using appropriate geotechnical/geophysical methods. In the current study, the investigation was performed in different development projects in southern part of Egypt using different geophysical methods [e.g. Shallow seismic refraction, Multichannel Analysis of Surface Waves (MASW), ambient vibration measurements and Probabilistic Seismic Hazard Analysis (PSHA)].

Due to the importance of Aswan area and its neighborhood to the High Dam, many seismic hazard studies have been carried out in this area and its surrounding (e.g., Elamin, 2011; Deif et al., 2011 and Fat-Helbary et al., 2008). Also, for site characterization, many studies have been performed in different development projects (New Aswan city, New Tushka city, Aswan 
[Type here]

Proceedings of the $\mathbf{1 2}^{\text {th }}$ ICCAE-12 Conference, 3-5 April, 2018

cement plant, Kurkur Nubian Habitation, New Qeft city; Aswan University) in South Egypt (e.g., Mohamed 2004 \&2010; Basheer, 2008; Fat-Helbary et al., 2012; Mohamed et al., 2013 and Arfa, 2015).

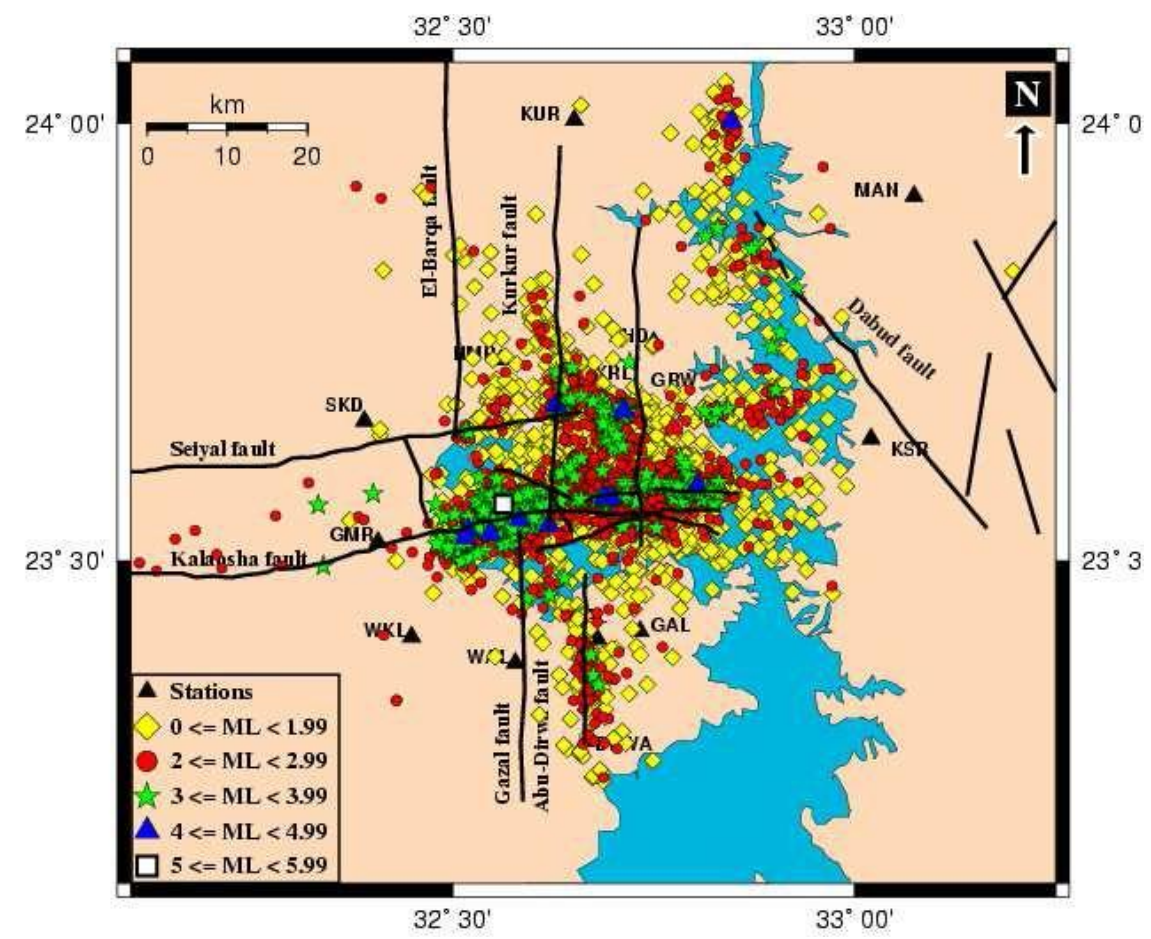

Figure 3. Seismic activity in Aswan area from 1982-2017.

\section{Geophysical case study in South Egypt}

\section{1- New Aswan city}

After the population has reached its maximum capacity around the two banks of the Nile River, the Egyptian government to construct new projects. These projects include the construction of a number of new cities. New Aswan city is one of these cities. Due to its location very close to the main active seismic zone in South Egypt (Kalabsha) it became of prime interest to carry out geophysical investigation study for the city to mitigate the earthquake risk in the city.

The main target of the study is a trial to investigate subsurface structure conditions, to determine the dynamic characteristics of the subsurface rocks and to study the effect of the near earthquake activities in the proposed location of the new Aswan city.

In this study, shallow seismic refraction method was applied to determine subsurface layering and the lateral and vertical changes in lithology, and investigate structural features such as, micro faults and cracks at the new Aswan city site. The evaluated seismic velocities are used in interpretation of lithology, structural features, rock material quality and dynamic characteristics, which are very useful for building and other civil engineering purposes. Seismic refraction survey was carried out using Strata Visor-NZ 48 channels. Nineteen seismic refraction $\mathrm{P}$-wave profiles and 19 seismic refraction S-wave profiles were conducted at the studied area. The P-and SH-wave velocities are computed from seismic refraction survey to the surface and bedrock layers. The output results indicated that the maximum value of the P-wave velocity of the first or surface layer is about $1050 \mathrm{~m} / \mathrm{sec}$ at the central part of the area while the minimum 
[Type here]

Proceedings of the $12^{\text {th }}$ ICCAE-12 Conference, 3-5 April, 2018

value is about $470 \mathrm{~m} / \mathrm{sec}$ at the northwestern part of the area where the sediments are loose (Fig. 4). On the other hand the SH-waves have the maximum velocity value about $580 \mathrm{~m} / \mathrm{sec}$ of the first or surface layer at the central part and the minimum value is about $280 \mathrm{~m} / \mathrm{sec}$ at the northwestern part of the area (Fig. 4).
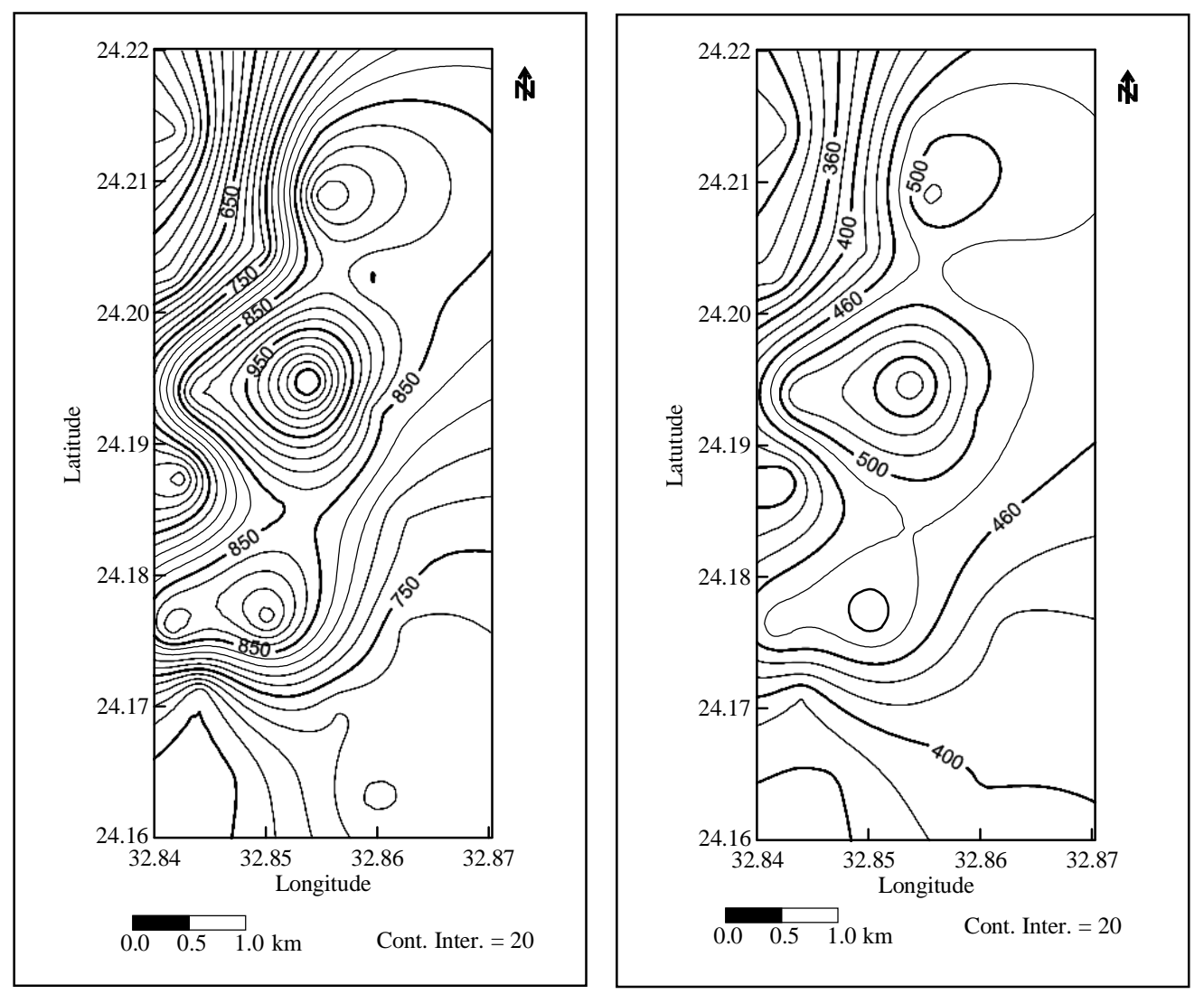

Figure 4. The P-waves (Left) and the SH-waves (Right) velocity distribution of the surface layer.

The P-wave velocity of the surface layers that calculated from seismic refraction survey used to calculate the bulk density. The bulk density for surface layers for each profile is calculated. Figure (5) shows the distribution calculated bulk density at the surface layer in the studied area. The maximum value of the surface layer is about $1700 \mathrm{~kg} / \mathrm{m}^{3}$ concentrated in the central part and the minimum value is about $1400 \mathrm{~kg} / \mathrm{m}^{3}$ which found in the northwestern part of the area.

\section{2- New Aswan University site}

One of the new universities in South Egypt is Aswan University. In 2012, the South Valley University branch in Aswan city was separated as a new University (Aswan University) and the Egyptian government financed the buildings of a new university campus. The new campus is located on the west bank of Nile in the newly urbanized and developed part of Aswan city. The campus's site is very close to the main active seismic zone in South Egypt that can generate strong earthquakes like the one that occurred on November, 1981 (M 5.6). On 
[Type here]

November 7, 2010 an earthquake was felt strongly (M 4.6) along spillway fault area, $16 \mathrm{~km}$ south to the new proposed Aswan University site and this earthquake was felt in Aswan urban area too. This earthquake encouraged us to perform geophysical investigations across the proposed Aswan University's campus to the mitigation of the earthquake risk. This study is focused on using ambient vibration measurements $(\mathrm{H} / \mathrm{V}$ spectral ration technique) to calculate the fundamental frequency and the amplification factor inside the new campus of the University. Due to the low cost and quick implementation of this technique, it is one of the most widely used methods for site response estimation using ambient vibration (microtremor) measurements, therefore this method was chosen to apply in Aswan University site. In 12 sites, the ambient vibrations were collected during the daytime and using the Taurus portable Seismograph and a three-component, force-balance broadband seismometer (Trillium 40s).

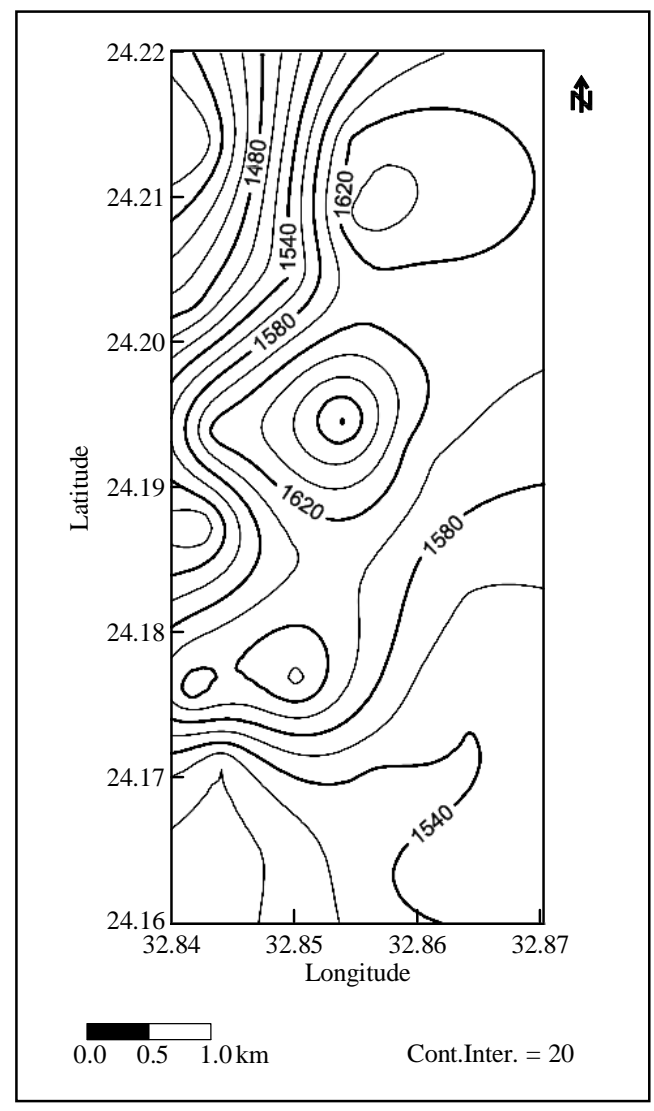

Figure 5. The bulk density variation of the surface layer at the study area.

The output results of this study at the selected sites were investigated, some sites with clear peaks in the $\mathrm{H} / \mathrm{V}$ spectral ratio (the obtained $\mathrm{H} / \mathrm{V}$ spectral ratio curve is reliable), which indicates that site effects might be expected at these sites. Some sites have no peak in the H/V spectral ratios (the $\mathrm{H} / \mathrm{V}$ ratio is flat without meaningful peaks). At these sites, presence of shallow hard sediments or bedrock condition might be assumed and this is coincides with the results obtained by Mohamed (2004) in and around the study area, so the shallow bedrocks in the proposed site may have a direct effect on the measured peak frequency. The fundamental frequency $\left(f_{o}\right)$ in the study area ranges from 0.77 to $1.03 \mathrm{~Hz}$ (Fig. 6). The minimum fundamental 
[Type here]

Proceedings of the 12 $2^{\text {th }}$ ICCAE-12 Conference, 3-5 April, 2018

frequency value is about $0.77 \mathrm{~Hz}$ along the southern corner of the study area, while the maximum value is about $1.03 \mathrm{~Hz}$ and observed along the eastern part of the area. The amplification factor (maximum $\mathrm{H} / \mathrm{V}$ amplitude $\mathrm{A}_{\mathrm{o}}$ ) ranges from 1.4 at the eastern part to 3.6 at the northwestern part of the study area. (Fig. 7).

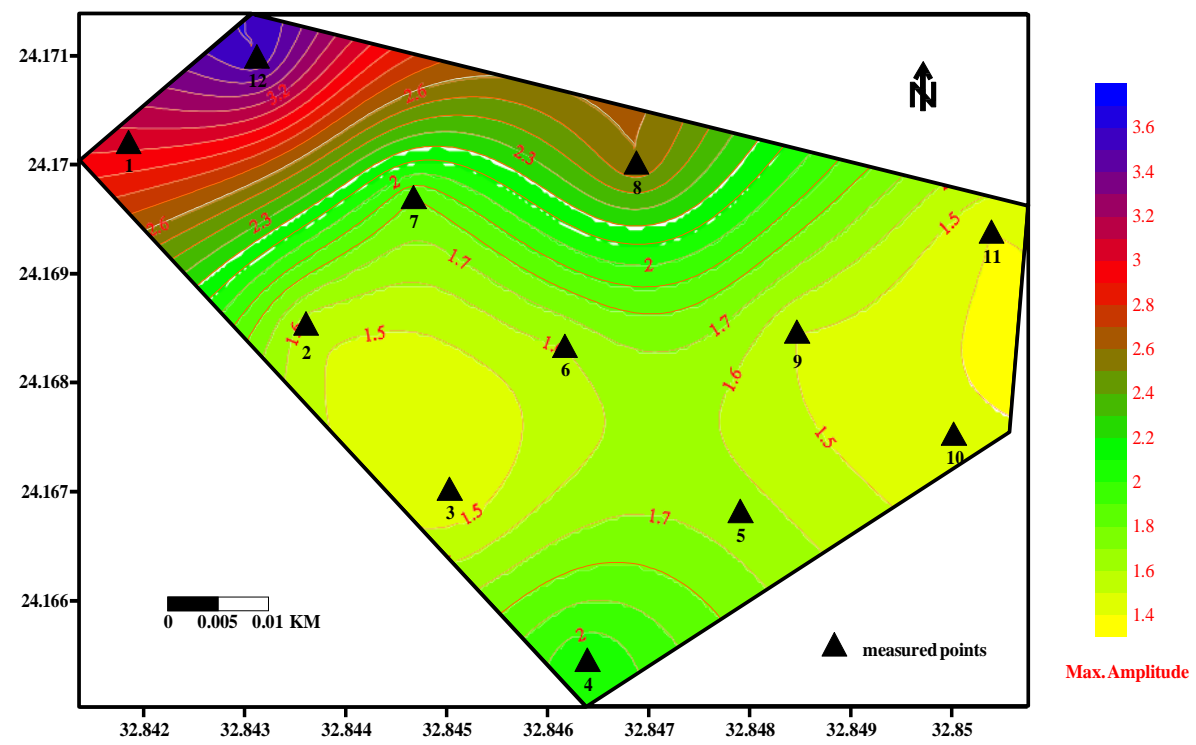

Figure 6. The amplification factor (maximum amplitude of $H / V$ ) at the study area.

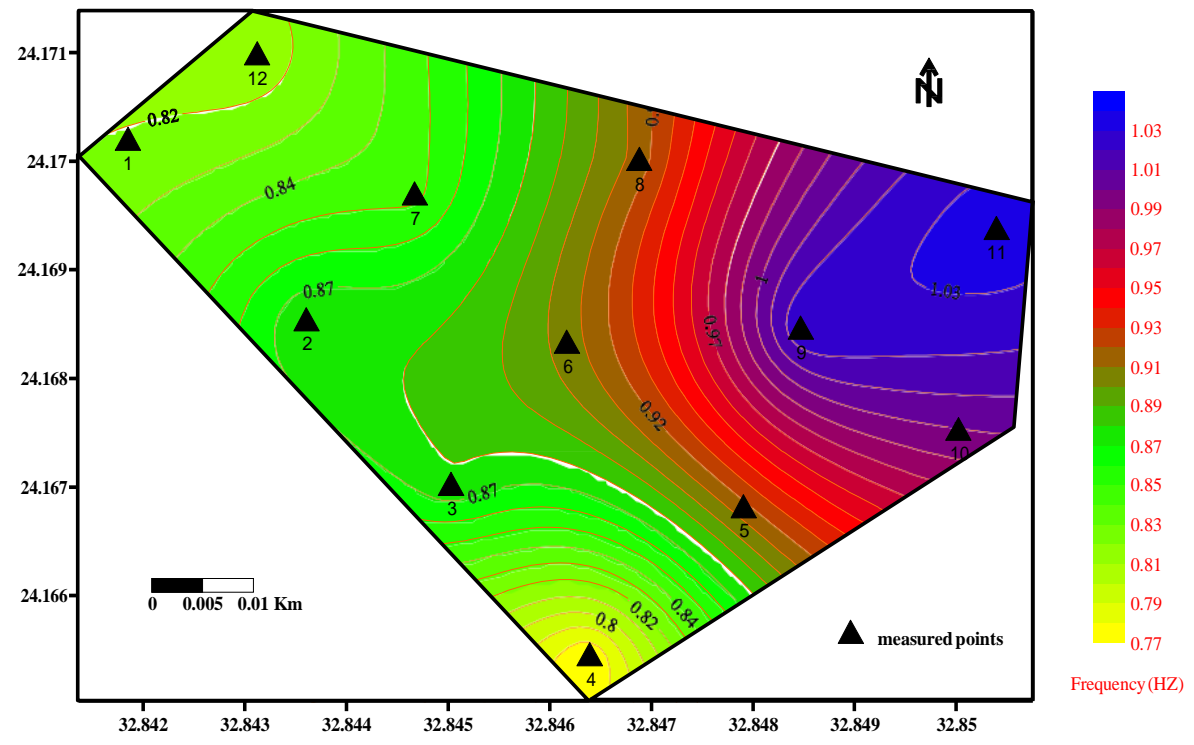

Figure 7. The fundamental frequency at the study area.

\section{Conclusion and recommendations}

Site characterization using Geophysical and geotechnical techniques is the primary valuable step in earthquake risk mitigation. The results demonstrate the usefulness of the H/V 
[Type here]

Proceedings of the $12^{\text {th }}$ ICCAE-12 Conference, 3-5 April, 2018

spectral ratio method using microtremors and shallow seismic refection technique in order to provide reliable information on the dynamic behavior of surficial layers.

Finally, these studies strongly recommend applying in planning stage of all the new development projects and strategic buildings and there output results should be taking into consideration to design and construct seismically resistant structures.

\section{References}

Arfa, M. (2015): Engineering seismological studies for the new Nubian habitations area in Wadi Kurkur, Aswan, M.Sc thesis, Al-Azhar University.

Basheer, A. (2008): Geophysical study on the new Qeft city, Qena, Egypt, PhD thesis, South Valley University.

Daggett P., Morgan P., Boulous F., Hennin S., El-Sherif A., El-Sayed A., Basta N. and Melek Y. (1986): Seismicity and Active Tectonics of the Egyptian Red Sea Margin and the Northern Red Sea. Tectonophysics; 125: 313-324.

Daniell, J. E. Khaza, B. Wenzel, F. Vervaeck, A. 2011. The CATDAT damaging earthquakes database, Nat. Hazards Earth Syst. Sci.11, 2235.

Deif A., Hamed H., Igrahim H. A., Abou Elenean K., and El-Amin E. M. (2011): Seismic Hazard Assessment in Aswan, Egypt, Journal of Geophysics and Engineering 2011; 8: 531-548.

El-Amin E. M. (2011): Study of Seismic Hazard Analysis Using Fault Parameter Solutions in Aswan Region, Upper Egypt. PhD thesis, Assiut University, Egypt.

Fat-Helbary R. E. (1989): A Study of the Local Earthquake Magnitude Determination Recorded by Aswan Seismic Network, M.Sc thesis, Assiut University, Sohag Branch, Egypt.

Fat-Helbary R. E. and Tealeb A. A. (2002): Study of Seismicity and Earthquake Hazard at the Proposed Kalabsha Dam Site, Aswan, Egypt. Natural Hazards; 25: 117-133.

Fat-Helbary R. E., El Khashab H. M., Dojcinovski D., El Faragawy K. O., and Abdel-Motaal A. M. (2008): Seismicity and Seismic Hazard Analysis in and around the Proposed Tushka New City Site, South Egypt. Acta Geodynamica et Geomaterialia 2008; 5 (4) 389-398.

Fat-Helbary R. E., Kamal Abdelrahman, Fnais. M. S. and Abdelmoneim. E (2012): Seismic Hazard and Site Response Assessment on the Proposed Site of Aswan Cement Plant, Egypt. International Journal of Earth Science 5(4), 644-651.

Issawi B. (1968): The Geology of Kurkur-Dungul Area. General Egyptian Organization for Geological Research and Mining; Cairo, Egypt. Geological Survey. No. 46, 101 pp.

John Rees, Sue Loughlin, David Tappin, Philip England, David Petley, Jenni Barclay and John McCloskey (2012): Anticipation of Geophysical Hazards, Report produced for the Government Office of Science, Foresight project 'Reducing Risks of Future Disasters: Priorities for Decision Makers.

Kebeasy, R. M., Maamoun, M. and Ibrahim, E. (1982): Aswan Lake Induced Earthquakes; Bulletin of the International institute of Seismology and Earthquake Engineering, V. 19, pp. 155-160, Japan.

Mohamed, A. (2004): Engineering seismological studies on the location of Aswan new city, M.Sc thesis, Aswan University.

Mohamed, A. (2010): Engineering seismology studies for land-use planning at the proposed Tushka new city site, South Egypt, PhD thesis, Aswan University.

Mohamed, A., Fat-Helbary R. E., Basheer, A. and Dojcinovski, D. (2013): Using ambient vibrations for site characterization at the new Aswan university site, southern Egypt. 
[Type here]

Proceedings of the $12^{\text {th }}$ ICCAE-12 Conference, 3-5 April, 2018

SE50EEE International Conference on Earthquake Engineering, Macedonia, 29-31 May, 2013.

NEHRP (2003): Recommended provisions for seismic regulations for New Buildings and Other Structures. Building Seismic Safety Council (BSSC) for the Federal Emergency Management Agency (FEMA 450). Washington, Part 1: Provisions.

WCC-Woodward-Clyde Consultants (1985): Earthquake activity and stability evaluation for the Aswan High Dam. Unpublished report. High and Aswan Dam Authority, Ministry of Irrigation, Egypt. 